\title{
Expansion and Internal Changes of Ger Areas in Ulaanbaatar, Mongolia, with an Analysis Using Aerial Photography
}

\section{MATSUMIYA Yuko}

Graduate School of Arts and Letters, Meiji University; 1-1 Kandasurugadai, Chiyoda-ku, Tokyo 101-8301, Japan.

E-mail:yukusako23@gmail.com

Received December 20, 2016; Accepted March 16, 2017

\begin{abstract}
The suburban area of Ulaanbaatar, the capital city of Mongolia, has an extensive "Ger area" where residents live in Ger or Bai-shin. Recently, Ger areas have reportedly expanded in accordance with the increasing population. Previous studies of Ger areas have tended to focus on the "unique sight" of Gers in the city and few have discussed the residents' point of view. For this study, the two analyses focus on and clarify the changes in Ger areas over time, using aerial photographs, first to clarify Ger areas' expansion, the regions that corresponded either to "Ger areas," consisting of continuous Kha-shaas, or "Apartment areas," consisting of apartments or modern buildings, which were marked by lines. The second is to clarify the internal changes in Kha-shaas, and identify individual Kha-shaa, Ger and Bai-shin within each Kha-shaa marked at three selected sites. In addition, Kha-shaa were counted and categorized according to whether they contained "Ger only", "Ger and Bai-shin", or "Bai-shin only." Through these analyses the clarified Ger areas were understood to be redeveloped for apartments in the socialist era but after democratization the promised development did not take place. Old Kha-shaa consisted of "Bai-shin only" or "Ger and Bai-shin", and new Kha-shaa consisted of "Ger only". In other words, Ger have been gradually decreasing because of the building of Bai-shin, which are more comfortable and convenient for urban living. Although progressively more Bai-shin are being built over time, Ger do not disappear because they are being used for different purposes by residents. Those who relocate to Ulaanbaatar rely on family members who live in Ger areas for temporary accommodation in their Ger. "Gers in the city" not only means a unique sight but also living in a Ger is very rational in urban life.
\end{abstract}

Key words Ger area, urbanization, housing type, land lot, aerial photograph, Ulaanbaatar, Mongolia

\section{Introduction}

\section{Background}

Ulaanbaatar, the capital city of Mongolia, consists of two different types of residential areas: Apartment areas, which are located in the central part of the city, and "Ger areas," which are located in the suburbs. Although Ger areas have reportedly expanded in accordance with an increasing population, the details of this expansion remain unclear.

Residents of the Ger areas live in Gers, which are circular domed tents made of felt (sheep wool) stretched over a wooden frame that represents a traditional type of housing among those living a nomadic lifestyle; they are also known as "Yurts" in Turkey or "Paos" in China. In most cases, settlers from rural areas moving to Ulaanbaatar bring their Gers with them. They eventually build their own permanent houses, known as Bai-shin in Mongolian, using wood, mud, and cement and surround them with wooden fences; this type of area is known as a "Kha-shaa" in Mongolian (Figure 1 and 2). The residential environment of a Ger area is typically supplied with electricity, but lacks running water, sewage disposal, and heating systems. Although residents live in traditional housing such as Gers, their lives can be considered "urban" or "modern" in that they use electrical appliances such as refrigerators, washing machines, and TVs. The government had already recognized the seisin for Ger area residents, but a New Land Law issued in 2002 gave specific rights to landowners.

\section{Previous research}

Previous studies about Ger areas have tended to focus on the "unique sight" of Gers in the city and the problems they encounter in their living environments, such as overpopulation and the lack of running water, sewage disposal, and heating systems; likewise few studies have investigated the framework of the gradually advancing urbanization process, which should be informed by the intentions of Ger residents. 


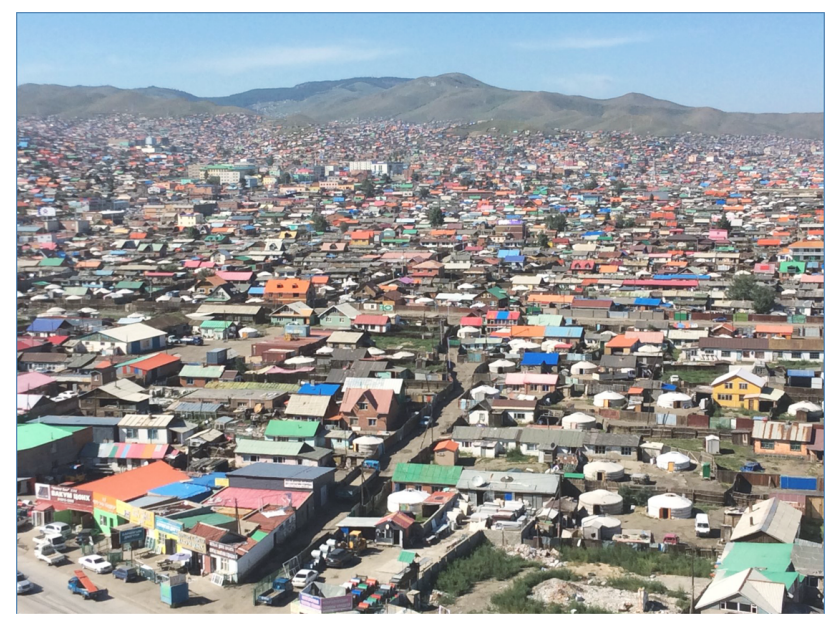

Figure 1. Ger areas at close to city center. Taken by author in August, 2015.

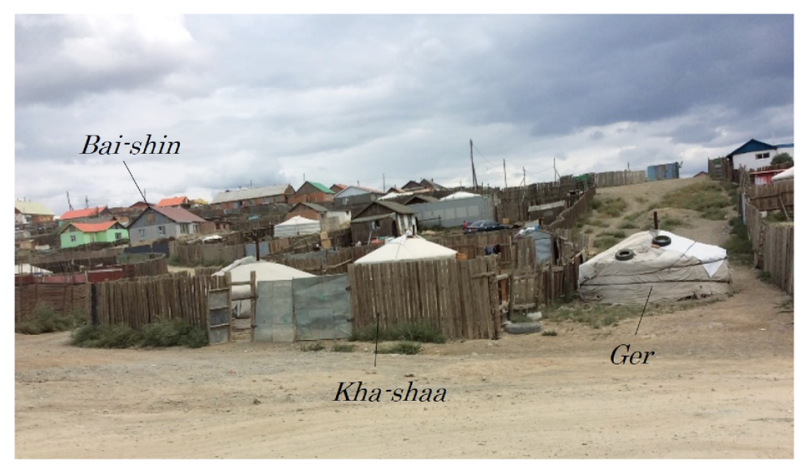

Figure 2. Ger areas at suburban. Taken by author in August, 2015

Tumenjargal (2002) and Kushiya et al. (2007) interviewed Ger area residents regarding the residential environment to investigate attributes such as type of housing, occupation, income, previous residence and desire for a specific type of residential environment. Chinbat (2010) also conducted similar surveys and interviewed apartment residents. In these surveys, residents reported that poverty, a lack of running water, and a lack of sewage disposal made their lives difficult. Second, Takiguchi (2009) and Ishii (2012a, 2012b) investigated trends after the implementation of the New Land Law in 2002 (effective in 2003). According to Minato (2002), this law gave distinct rights to landowners, and promoted land ownership for Ger area residents. In Ulaanbaatar, the maximum surface area of a property is $700 \mathrm{~m}^{2}$, and each Mongolian citizen can register their land for free only once $^{1}$. This led to a boom in landownership in Mongolia and a rapid increase in the number of landowners in Ger areas. According to Takiguchi (2009), landowners had to not only register, but also live on their land. Batbold and Majima (1998) and Chinbat (2008) studied Ger areas in terms of urban development, focusing on current condi- tions and domestic housing policy. In the socialist era, Ger were considered temporary residences that would be redeveloped into apartments in the future. In that era, most of the citizens living in Ger areas were doing so with the expectation that the Government would eventually build and provide apartments for them; however, this was not the case. Ishii $(2014 a, 2014 b)$ referred to this issue in a study on current redevelopment in the city ${ }^{2}$.

These previous studies have had some limitations. First, because these studies targeted specific Ger areas, whether the findings can be generalized to all Ger areas remains unclear. In addition, these studies treated all Ger areas equally, were limited in scope, and collected data through interviews. In other words, little effort has been directed towards identifying the reasons behind the formation of Ger areas and the process of expansion within a Mongolian socioeconomic context, or towards considering how newcomers have created new urban spaces. Studies of cities in other countries have investigated urbanization processes or the characteristics of residential spaces; however, studies focusing on the morphological uniqueness and urbanization process of Ulaanbaatar have revealed very little. Furthermore, the urbanization of Ulaanbaatar and expansion of Ger areas have not been compared with cities in other countries. Therefore, owing to a paucity of accumulated studies, less is understood about Ulaanbaatar than other cities. Second, from the beginning, Ger areas have been understood to comprise an urban problem that is in need of improvement. The findings from these studies have influenced organizations such as JICA (2002), UN-Habitat (2010), the Kamata et al. (2010), and Amrjargal (2012) as well as international organizations and government approaches to improving living environments in Ger areas. Such organizations have thus regarded Ger areas in Ulaanbaatar as slums and those living in them as squatters in cities in developing countries. In fact, the expansion of Ger areas has caused increasingly critical levels of air pollution and vulnerability to disasters. Ger areas are now designated for urban redevelopment.

However, the city of Ulaanbaatar began as a Ger settlement. Thus, Ger areas should be understood as areas in which newcomers build Gers, establish districts and construct Bai-shin. Based on this premise, as well as reviews and field surveys, residents of Ger areas perceive them as places where they can establish a temporary home in which to settle and then improve their living conditions over time by eventually constructing permanent housing such as Bai-shin. In terms of landownership and living conditions, Ulaanbaatar's Ger areas can be regarded as 
different from the slums and squatter communities commonly found in cities in other developing countries.

\section{Purpose of this study}

The purposes of this study was to clarify morphological changes over time in Ger areas by using aerial photographs. The reason for using aerial photographs is as follows: first, previous research is subjectively considered by interview surveys. In contrast, aerial photographs can take an objective and quantitative view of Ger areas. In addition, this study seeks to address the questions left unanswered by previous studies on characteristics of location of Ger areas.

Some previous studies have used aerial photography for their analysis (Amarsaikhan et al. 2009; Tsutsumida 2013). In an analysis of aerial photographs from 2000, 2006 and 2008, Tsutsumida (2013) identified and counted the number of Kha-shaa and Ger one-by-one using geographic information systems (GIS), which clarified the extent of outward expansion of Ger areas. However, the internal change and locality distinctions remain largely unknown. It is necessary to focus on internal Kha-shaa because the residents of Ger areas are said to change from Ger to Bai-shin over time.

This study has two main analysis. The first one is to clarify the process of Ger areas' expansion over time, including the characteristics of distinct localities within the collective Ger areas. The second is to clarify the internal changes that have occurred within Ger areas. Assuming that the intentions of residents do have an effect on the formation process, the focus is then on the reasons behind the expansion and internal changes of Ger areas, as well as the increase in the numbers of Kha-shaas. Furthermore, this research aims to clarify what is meant by "Gers in the city" other than providing "unique sight."

\section{Overview of the Study Area}

Ulaanbaatar is situated at lat. $47^{\circ} 92^{\prime} \mathrm{N}$. and long. $106^{\circ} 87^{\prime} \mathrm{E}$. Elevation is $1350 \mathrm{~m}$. It has an inland climate, hot in summer, cold in winter and little rain, typical of a basin.

Mongolia became a socialist state independent of the Qing at 1921, and after WWII, progressed to socialist modernization. In Ulaanbaatar, which was founded with the formation of settlements as the center of Tibetan Buddhism, city construction progressed to the form of a "capital city". At the same time, central Ger areas had been rebuilt to apartments in the context of urban planning. Ger areas were generally considered temporary residential areas slated for eventual development as apartment blocks. Many people who were called to Ulaanbaatar to work on city construction lived in Ger areas because of the lack of apartments.

Domestic population movement was managed by the government until transition to democracy in 1990. After that, residents of rural areas began moving to the city to seek out education and employment opportunities (Fujimoto 2005). Ulaanbaatar has recently undergone significant expansion in terms of population density and urban function. The population rapidly increased from approximately 560,000 by the end of 1990 to around 1.3 million by 2014, which is almost half of the entire national population (Figure 3 ). This increase was largely the result of the influx of people from rural areas since the 2000s. Fujimoto (2005) also referred to the influence of occurred of $d z u d^{3}$ in the late 1990's and the effect of the New Land Law in 2003.

The urban areas of Ulaanbaatar in 1974, 2000, and 2014 are shown in Figure 4. As shown in the figure, much of the urban and especially suburban expansion in

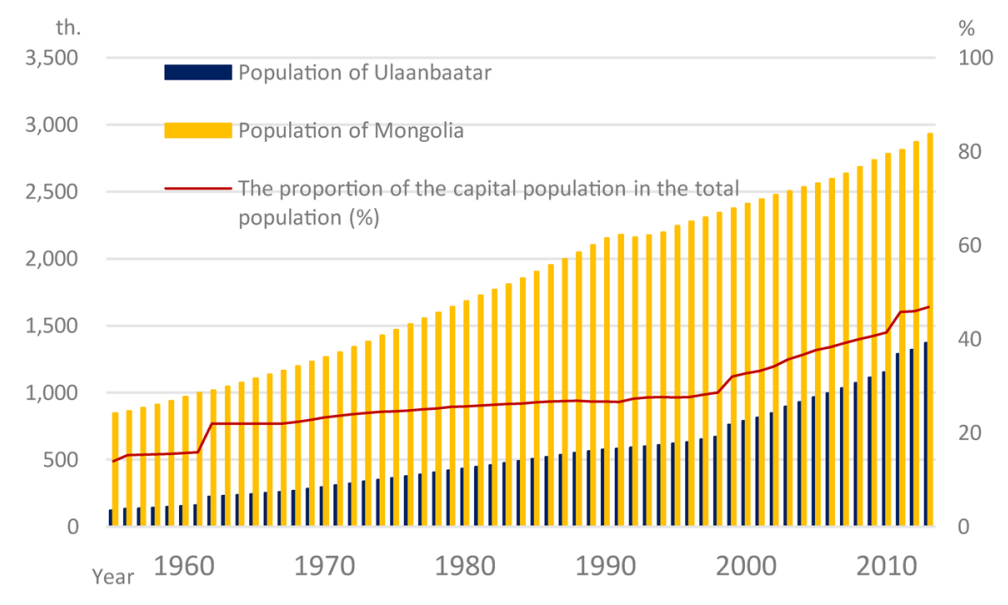

Figure 3. Population of Mongolia and Ulaanbaatar.

Source: Statistical office of Ulaanbaatar. 


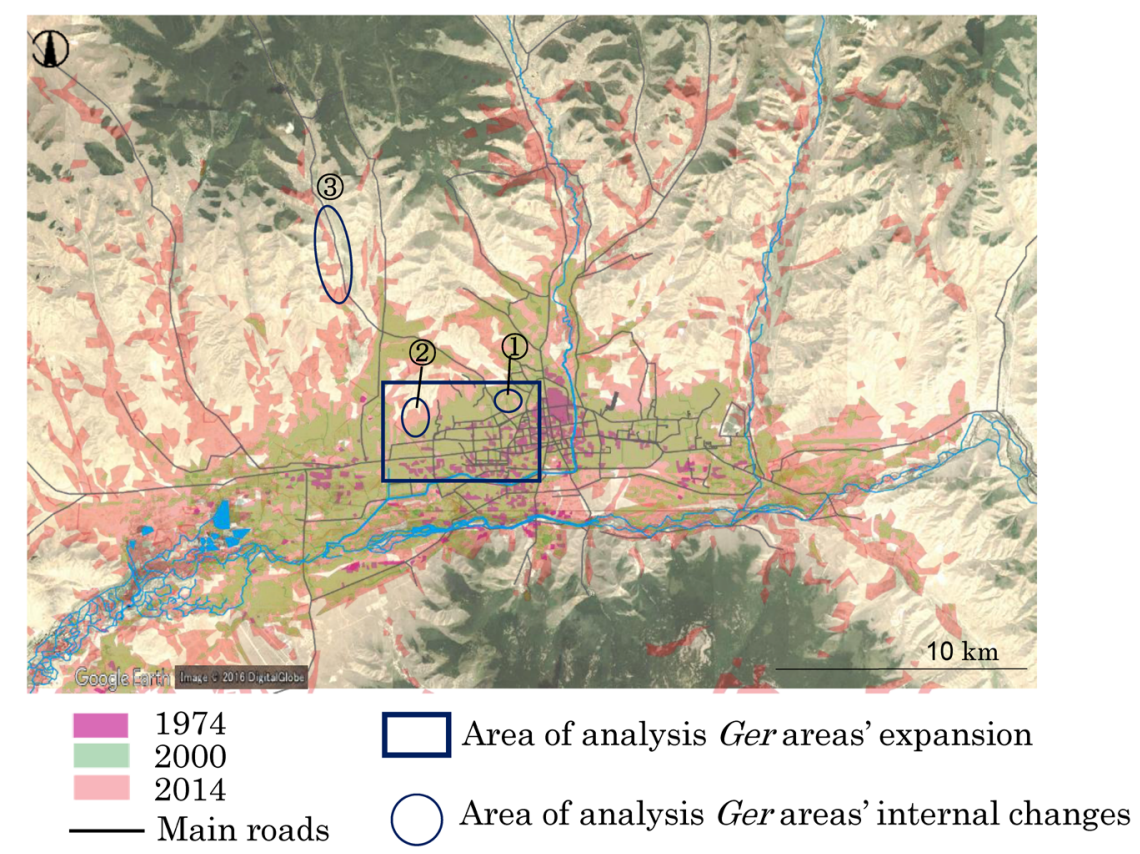

Figure 4. Urban areas of Ulaanbaatar.

Source: Created by author based on administrative documents of Ulaanbaatar and Google Earth.

Table 1. Types of housing in Ulaanbaatar (Household)

\begin{tabular}{|c|c|c|c|c|c|c|}
\hline & \multirow{2}{*}{ Total } & \multicolumn{2}{|c|}{ Apartment area } & \multicolumn{2}{|c|}{ Ger area } & \multirow{2}{*}{ No house } \\
\hline & & Apartment & Detached house & Ger & Bai-shin & \\
\hline \multirow{2}{*}{2000} & 161,273 & 76,593 & * & 35,230 & 48,325 & 1,125 \\
\hline & $100 \%$ & $47.5 \%$ & $\mathrm{n} / \mathrm{a}$ & $21.8 \%$ & $30.0 \%$ & $0.7 \%$ \\
\hline \multirow{2}{*}{2005} & 205,498 & 83,658 & 2,498 & 56,202 & 61,381 & 1,759 \\
\hline & $100 \%$ & $40.7 \%$ & $1.2 \%$ & $27.3 \%$ & $29.9 \%$ & $0.9 \%$ \\
\hline \multirow{2}{*}{2010} & 273,182 & 104,987 & 2,934 & 72,011 & 92,232 & 1,018 \\
\hline & $100 \%$ & $38.4 \%$ & $1.1 \%$ & $26.4 \%$ & $33.8 \%$ & $0.4 \%$ \\
\hline \multirow{2}{*}{2015} & 352,812 & 147,381 & 2,919 & 93,459 & 108,770 & 283 \\
\hline & $100 \%$ & $41.8 \%$ & $0.8 \%$ & $26.5 \%$ & $30.8 \%$ & $0.1 \%$ \\
\hline
\end{tabular}

* Including for Bai-shin.

Source: Statistical office of Ulaanbaatar \& Population and housing cecsus of Mongolia 2000.

Ulaanbaatar has occurred in Ger areas.

The types of housing available in the Apartment areas are primarily apartments and detached houses, while those in Ger areas consist of Gers and Bai-shin (Table 1). As described in the table, the number of detached houses is limited. While apartments and detached houses are accompanied by some degree of infrastructure, Gers and Bai-shin are not. The total number of households in Ulaanbaatar increased more than two-fold, from 161,000 to 353,000 , from 2000 to 2015 . Over the same period, the total number of Bai-shin also increased more than twofold, from about 48,000 to 109,000 , the number of Gers increased about 2.6-fold, from 35,000 to 93,000, and the number of apartments increased two-fold from 76,000 to 147,000 . However, the increasing number of apartments was much smaller than the number of Gers and Bai-shin until 2010. As shown in Table 1, 50\% of urban households lived in Ger areas in 2000, but this number increased to $60 \%$ by 2015 . It is reasonable to expect that those moving to urban areas in the 2000s primarily sought to live in Ger areas.

\section{Data and Methodology}

For this study, aerial photographs taken in 1975 and 2003 (images obtained from joint research by the Institute of Geography and Geoecology, Mongolian Academy of Sciences and Nagoya University), and in 2000 (MME Group Co. Ltd), as well as Google Earth images from 2005, 2006, 2014 and 2015, were used. 


\section{Expansion of Ger areas}

In this section, the suburban expansion of Ger areas is described. The aerial photographs used were taken in 1975, 2000, and 2014 and encompass the west side of the urban area of Ulaanbaatar ${ }^{4}$ (Figure 4). In 1975, which was during the socialist era, city construction was continued with development, while in 2000, about a decade had passed since the democratic revolution of 1990. This is also when the rapid population influx to urban areas began. The photographs from 2014 show the present situation and the changes that occurred from 2000-2014.

The aerial photographs from each year consist of several map sheets. First, all sheets were georeferenced oneby-one in Arc GIS and then combined into one sheet for each year. A close-up view of the aerial photographs allows Kha-shaas, Gers, Bai-shin and apartments to be identified one-by-one. Next, the regions that corresponded to either "Ger areas," consisting of continuous Kha-shaas, or "Apartment areas," consisting of apartments or modern buildings, were marked by lines using Adobe Illustrator (Figure 5-a).

\section{Internal changes in Kha-shaas}

To examine whether residential history bore any relation to residents' settlement practices, the focus of this section is on changes that took place inside Ger areas, especially inside Kha-shaas. According to interview surveys, residents reported opting to build Bai-shin rather than Gers as a result of their relative convenience for urban living (Matsumiya 2016). Therefore, I wished to confirm the actual conditions of these areas.

Three sites were selected for consideration in the analysis (Figure 4). Site 1 is relatively close to the city center, and had already included some Kha-shaas in 1975. Since then, Site 1 has remained a Ger area. Analysis of Site 1 used photographs of 1975, 2003 and 2014. The reason for choosing these periods is that the quality of data for analysis is the same as for the analysis of expansion of Ger areas. Site 2 is in between the city center and the suburbs, and was vacant in 1975, but in 2000, Kha-shaas started to appear close to the main road, and by $2014, \mathrm{Ger}$ areas had expanded into the suburbs. So, analysis of Site 2 used 2000 and 2014. Site 3 is in a suburban area on the outskirts of the city, about $15 \mathrm{~km}$ distance from the city center and 1.5 hours by bus. There were no Kha-shaa in 1975, but Kha-shaas were being constructed at this site as of 2015. Analysis of Site 3 used photographs of 2006 and 2015 on Google Earth. Site 3 in 2000 and 2003 could not be deciphered. Use of 2006 data was difficult while 2015 showed the most resent situation on Google Earth.

For this analysis, aerial photographs of each selected site were georeferenced using Arc GIS. Next, the aerial

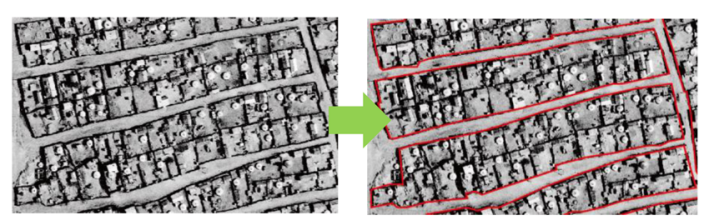

Ger Area which section of land consists of continuous kha-shaa $100 \mathrm{~m}$ (Photo of 2000)

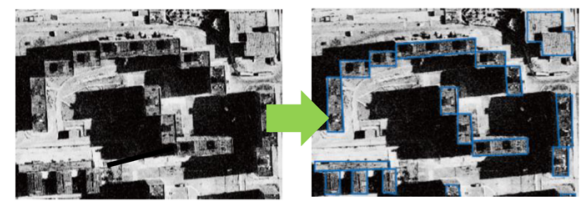

Apartment or building

a. Working method of Ger area' expansion
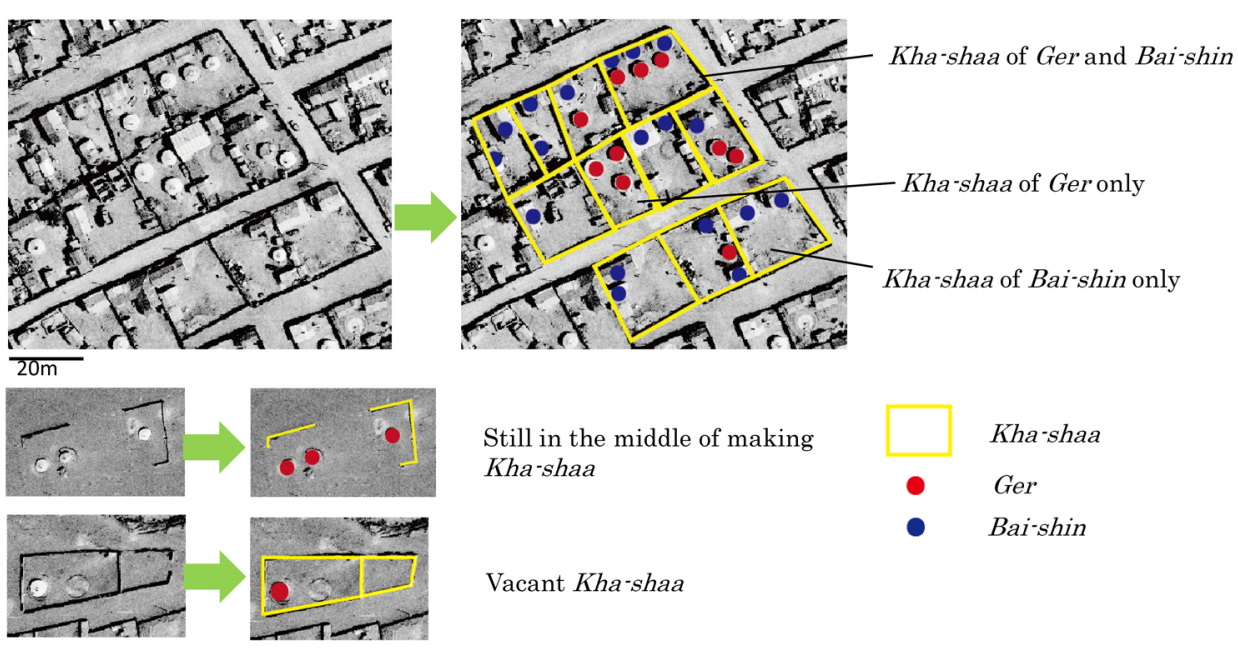

Still in the middle of making Kha-shaa

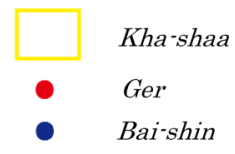

Vacant Kha-shaa

b. Working method of internal changes in Kha'shaas

Figure 5. Working method. 
photographs were magnified to identify individual Kha-shaas and then marked using Adobe Illustrator. In addition, Ger and Bai-shin within each Kha-shaa were identified (Figure 5-b), pointed red for Ger and blue for Bai-shin. Most Gers have a diameter of about $4.5-6.5 \mathrm{~m}$. Bai-shin come in various shapes and colors, and are generally the same size as or slightly larger than Gers. A typical Kha-shaa close to the city center is about $300 \mathrm{~m}^{2}$, while those in the suburbs are typically about $500 \mathrm{~m}^{2}$. Next, Kha-shaas were counted and categorized according to whether they contained "Ger only", "Ger and Bai-shin", or "Bai-shin only."

\section{Results}

\section{Results regarding suburban expansion}

By 2000, most of the Ger areas that had existed in 1975 had been replaced with apartment blocks, as shown in Figure 6. Areas that became Apartments areas are called

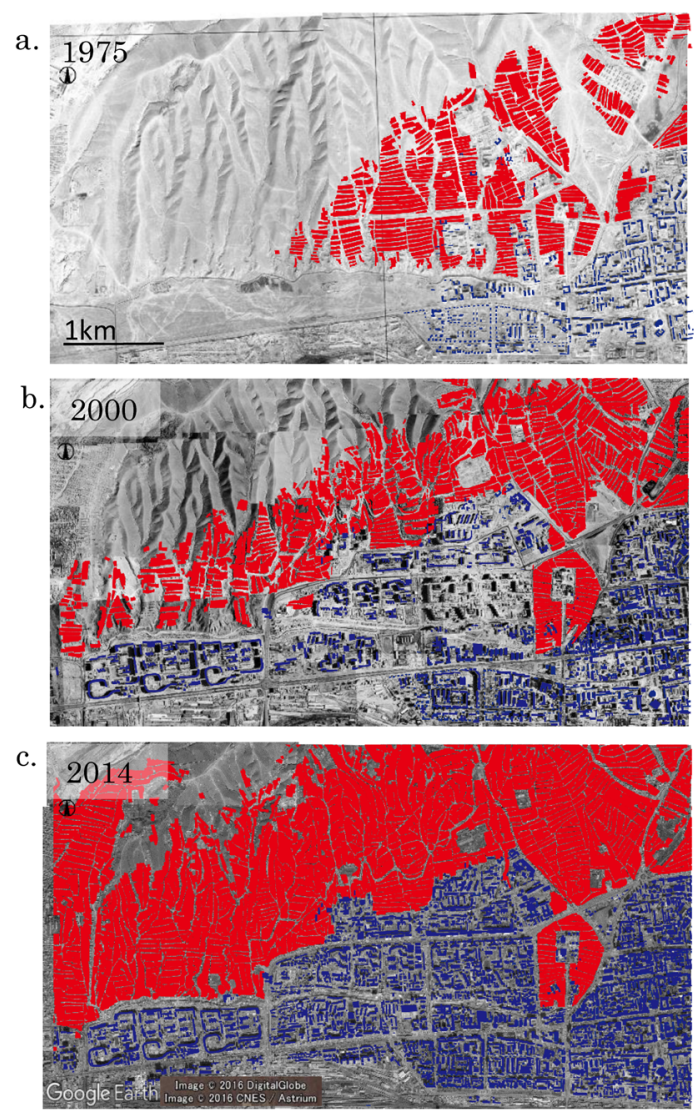

Ger area

Apartment or building

A. Ger area and Apartment area in each period
Third and Forth areas. These areas transformed from Ger areas to Apartment areas after the implementation of the Third Urban Master Plan (1978) in the socialist era, at which time, Ger areas were generally considered temporary residential areas slated for eventual development as apartment blocks in the context of urban planning. This is evidenced by the transformation that took place between 1975 and 2000. We can also see that in 2000, Ger areas had expanded into the northern sector of the city, which had been vacant in 1975 .

A decade later, in 2014, Ger areas had expanded further towards the northern and western sectors. Ger areas' expansion between 2000 and 2014 was considered pure expansion after the transition to democracy. Notably, by 2014, Ger areas that had remained undeveloped between 1975 and 2000 and those that had been newly formed in 2000 had expanded further into the suburbs. Moreover, they had not been replaced with apartments. In other words, this finding shows that the development of Ger
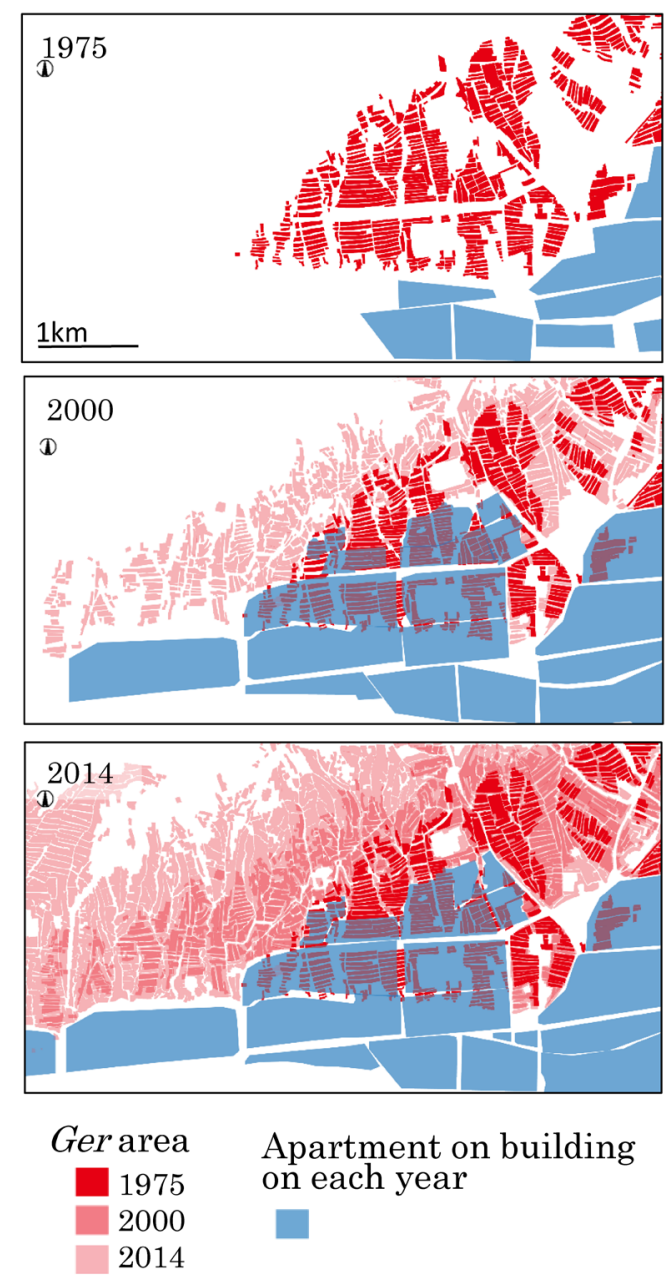

B. Superimposed image of $\mathrm{Ger}$ area and Apartment area in each period

Figure 6. Results of analysis of Ger areas' expansion.

a. 1975: Images obtained from joint research by Institute of Geography and Geoecology, Mongolian Academy of Sciences and Nagoya University. b. 2000: MME Group Co. Ltd. c. 2014: Google Earth. 

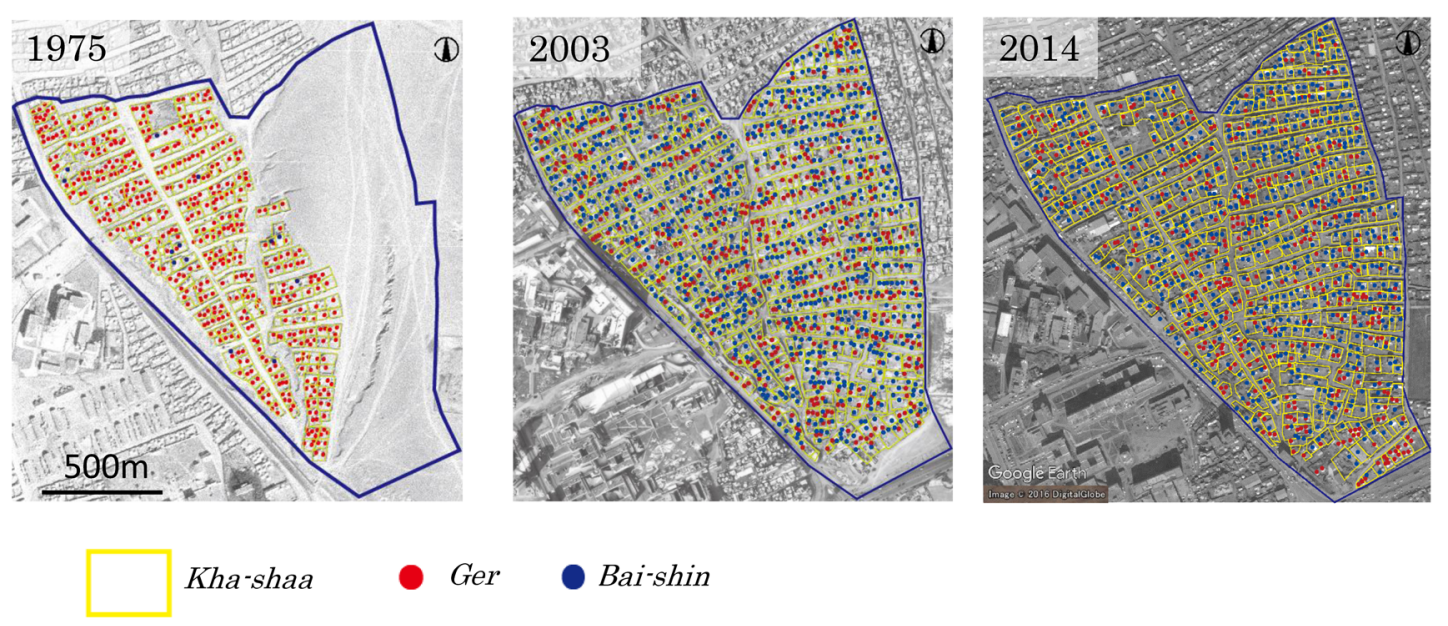

Figure 7. Results of each identified Kha-shaa, Ger and Bai-shin at Site 1.

a. 1975 and b. 2003: Images obtained from joint research by Institute of Geography and Geoecology, Mongolian Academy of Sciences and Nagoya University. c. 2014: Google Earth.

Table 2. Analysis of Internal changes in Kha-shaas of Site 1

\begin{tabular}{|c|c|c|c|c|c|}
\hline & $\begin{array}{c}\text { Total } \\
\text { Kha-shaa }\end{array}$ & $\begin{array}{c}\text { Ger } \\
\text { only }\end{array}$ & $\begin{array}{c}\text { Bai-shin } \\
\text { only }\end{array}$ & $\begin{array}{c}\text { Ger and } \\
\text { Bai-shin }\end{array}$ & Vacant \\
\hline \multirow{2}{*}{1975} & 222 & 207 & 3 & 10 & 2 \\
\cline { 2 - 6 } & $100 \%$ & $93 \%$ & $1 \%$ & $5 \%$ & $1 \%$ \\
\hline \multirow{2}{*}{2003} & 585 & 64 & 220 & 298 & 3 \\
\cline { 2 - 6 } & $100 \%$ & $11 \%$ & $38 \%$ & $51 \%$ & $1 \%$ \\
\hline \multirow{2}{*}{2014} & 604 & 105 & 295 & 199 & 5 \\
\cline { 2 - 6 } & $100 \%$ & $17 \%$ & $49 \%$ & $33 \%$ & $1 \%$ \\
\hline
\end{tabular}

Source: Analysis by author.

areas into apartment blocks had not progressed since the transition from the socialist era to democracy.

Therefore, Ger areas can be classified into two types, namely 1) "Areas planned for housing development in the socialist era but remained undeveloped after the political transition" and 2) "Areas newly formed as a result of population increases following democratization."

\section{Results regarding internal changes}

Close to the city center At Site 1 , which is close to the city center, the formation of Kha-shaas had already started in 1975, but only on the west side of this area (Figure 7, Table 2). Almost all Kha-shaas fell into the "Ger only" category. By 2003, Kha-shaas had formed across the entire site, with $90 \%$ of an entire Kha-shaa consisting of Bai-shin. However, in the period from 2003-2014, these Kha-shaas did not appear to undergo any major changes in terms of either composition or appearance, as $80-90 \%$ of an entire Kha-shaa still consisted of Bai-shin.

For 2003 and 2014, Kha-shaas at each site were further divided into the following two categories: (A) west
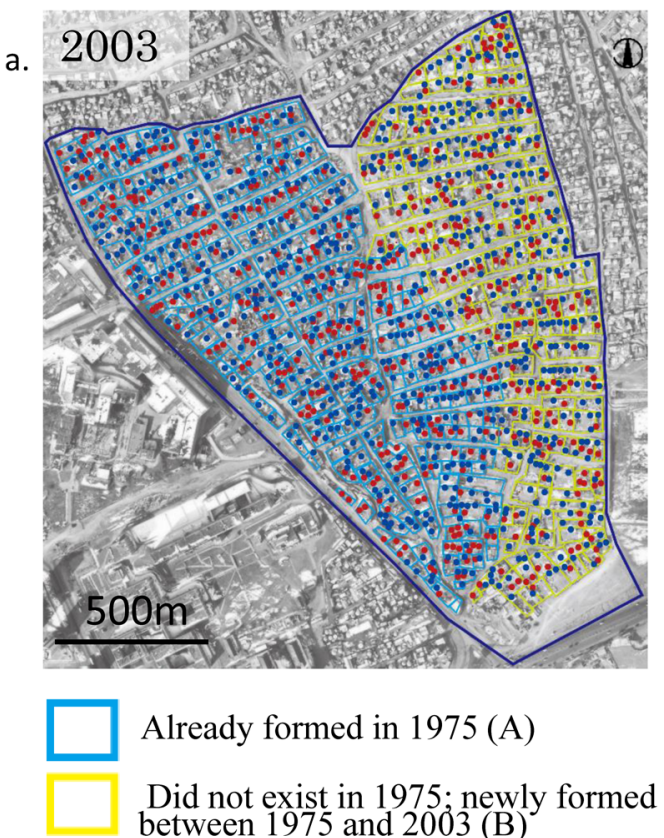

Did not exist in 1975: newly formed
between 1975 and 2003 (B)

- Ger Bai-shin

Figure 8. Further divided Kha-shaas at Site 1 in 2003.

a. 2003: Images obtained from joint research by Institute of Geography and Geoecology, Mongolian Academy of Sciences and Nagoya University.

side, which had already existed in 1975; and (B) east side, which came into existence between 1975 and 2003 (Figure 8 and 9, Table 3 and 4). However, few differences were seen in the composition of each Kha-shaa.

Middle area At Site 2, which is in between the city center and the suburbs, no Kha-shaas existed in 1975, but by 2000 , they had started to appear in the south, close to the city center (Figure 10, Table 5). In 2000, many Khashaas consisted of vacant lots, but by 2014, the number of Kha-shaas had increased 4-fold, from 615 to 2,472. Kha- 
shaas appear to have filled the gap between those already formed in 2000 and the areas to the north. By 2014, 58\% of an entire Kha-shaa consisted of Bai-shin.

For 2014, Kha-shaas at each site were further divided into the following two categories: (A) those that already existed in 2000; and (B) those that came into existence between 2000 and 2014 (Figure 11, Table 6). The Khashaas in Category A consisted of about $80 \%$ Bai-shin. On the other hand, the Kha-shaas in Category B consisted
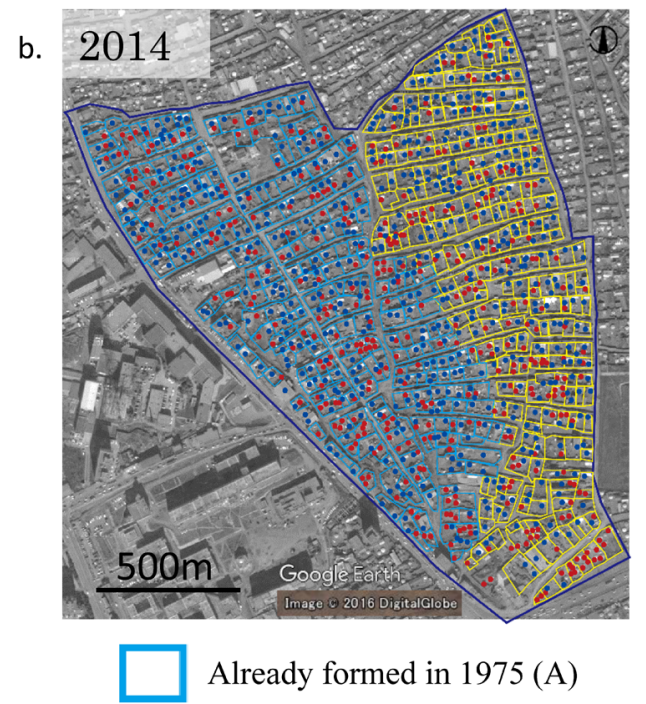

Did not exist in 1975; newly formed between 1975 and 2003 (B)

\section{- Ger Bai-shin}

Figure 9. Further divided Kha-shaas at Site 1 in 2014. b. 2014: Google Earth.

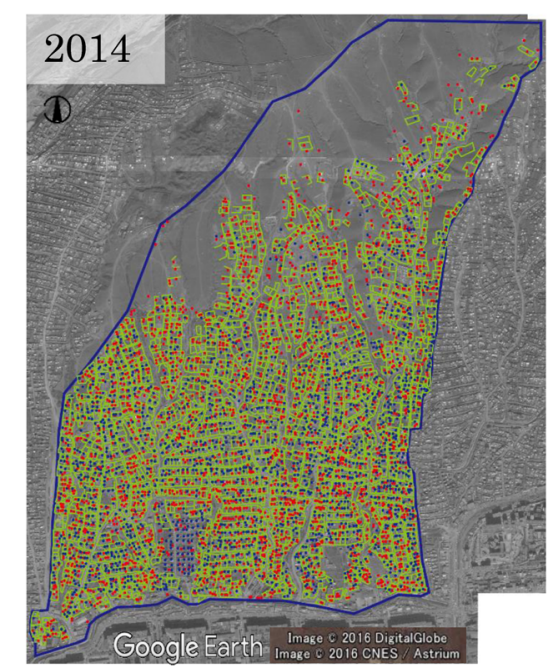

Source: Analysis by author.
A: Already formed in 1975. B: Did not exist in 1975; Newly formed between 1975 and 2003. Source: Analysis by author.

Table 5. Analysis of Internal changes in Kha-shaas of Site 2

\begin{tabular}{|c|c|c|c|c|c|}
\hline & $\begin{array}{c}\text { Total } \\
\text { Kha-shaa }\end{array}$ & $\begin{array}{c}\text { Ger } \\
\text { only }\end{array}$ & $\begin{array}{c}\text { Bai-shin } \\
\text { only }\end{array}$ & $\begin{array}{c}\text { Ger and } \\
\text { Bai-shin }\end{array}$ & Vacant \\
\hline \multirow{2}{*}{2000} & 615 & 282 & 139 & 82 & 112 \\
\cline { 2 - 6 } & $100 \%$ & $46 \%$ & $23 \%$ & $13 \%$ & $18 \%$ \\
\hline \multirow{2}{*}{2014} & 2,472 & 922 & 768 & 668 & 114 \\
\cline { 2 - 6 } & $100 \%$ & $37 \%$ & $31 \%$ & $27 \%$ & $5 \%$ \\
\hline
\end{tabular}

Table 3. Analysis divided into the following two categories of Site 1 in 2003

\begin{tabular}{|c|c|c|c|c|c|}
\hline & $\begin{array}{c}\text { Total } \\
\text { Kha-shaa }\end{array}$ & $\begin{array}{c}\text { Ger } \\
\text { only }\end{array}$ & $\begin{array}{c}\text { Bai-shin } \\
\text { only }\end{array}$ & $\begin{array}{c}\text { Ger and } \\
\text { Bai-shin }\end{array}$ & Vacant \\
\hline \multirow{2}{*}{$\mathrm{A}$} & 346 & 37 & 136 & 171 & 2 \\
\cline { 2 - 6 } & $100 \%$ & $11 \%$ & $39 \%$ & $49 \%$ & $1 \%$ \\
\hline \multirow{2}{*}{ B } & 239 & 28 & 84 & 127 & 0 \\
\cline { 2 - 6 } & $100 \%$ & $12 \%$ & $35 \%$ & $53 \%$ & $0 \%$ \\
\hline
\end{tabular}

A: Already formed in 1975. B: Did not exist in 1975; Newly formed between 1975 and 2003.

Table 4. Analysis divided into the following two categories of Site 1 in 2014

\begin{tabular}{|c|c|c|c|c|c|}
\hline & $\begin{array}{c}\text { Total } \\
\text { Kha-shaa }\end{array}$ & $\begin{array}{c}\text { Ger } \\
\text { only }\end{array}$ & $\begin{array}{c}\text { Bai-shin } \\
\text { only }\end{array}$ & $\begin{array}{c}\text { Gerand } \\
\text { Bai-shin }\end{array}$ & Vacant \\
\hline \multirow{2}{*}{$\mathrm{A}$} & 312 & 58 & 146 & 107 & 1 \\
\cline { 2 - 6 } & $100 \%$ & $19 \%$ & $47 \%$ & $34 \%$ & $0 \%$ \\
\hline \multirow{2}{*}{ B } & 292 & 47 & 150 & 91 & 4 \\
\cline { 2 - 6 } & $100 \%$ & $16 \%$ & $51 \%$ & $31 \%$ & $1 \%$ \\
\hline
\end{tabular}

\section{Site 2}

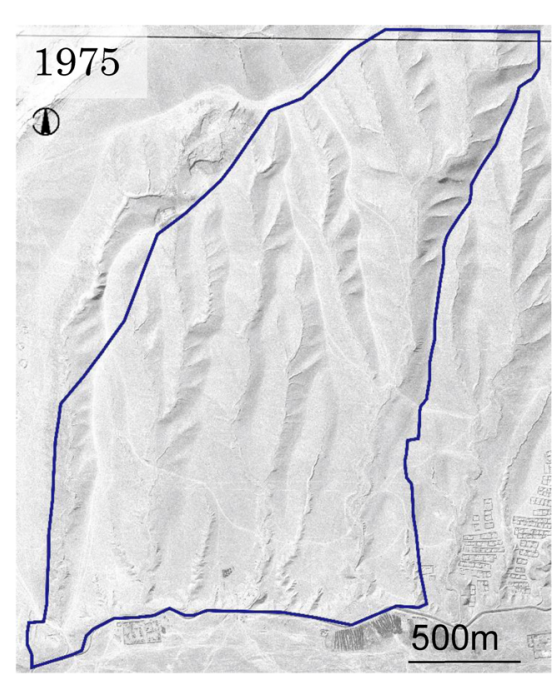

\section{Kha-shaa}

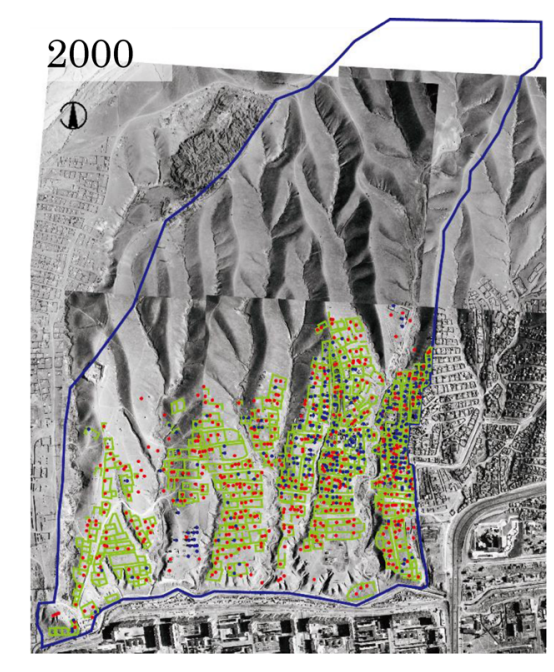

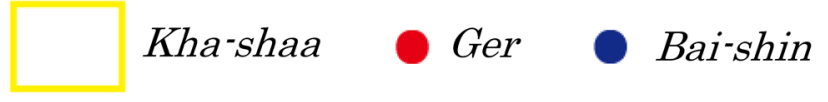

Figure 10. Results of each identified Kha-shaa, Ger and Bai-shin at Site 2.

a. 1975: Images obtained from joint research by Institute of Geography and Geoecology, Mongolian Academy of Sciences and Nagoya University. b. 2000: MME Group Co. Ltd. c. 2014: Google Earth. 
a.

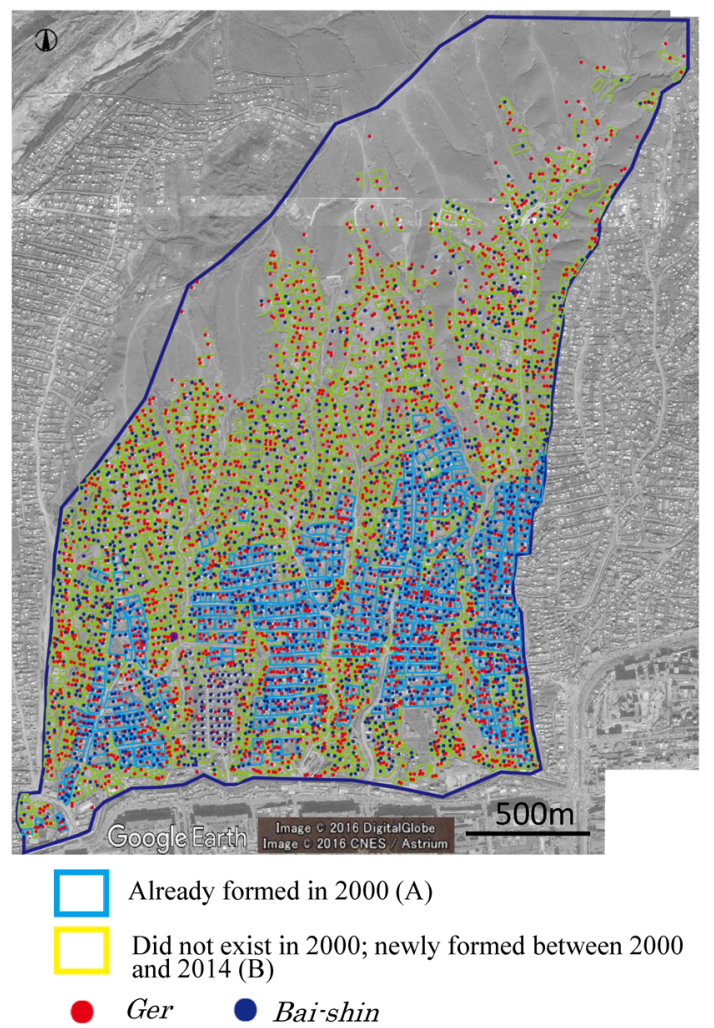

Figure 11. Further divided Kha-shaas at Site 2. a. 2014: Google Earth.

Table 6. Analysis divided into the following two categories of Site 2 in 2014

\begin{tabular}{|c|c|c|c|c|c|}
\hline & $\begin{array}{c}\text { Total } \\
\text { Kha-shaa }\end{array}$ & $\begin{array}{c}\text { Ger } \\
\text { only }\end{array}$ & $\begin{array}{c}\text { Bai-shin } \\
\text { only }\end{array}$ & $\begin{array}{c}\text { Ger and } \\
\text { Bai-shin }\end{array}$ & Vacant \\
\hline \multirow{2}{*}{ A } & 745 & 160 & 310 & 261 & 14 \\
\cline { 2 - 6 } & $100 \%$ & $21 \%$ & $42 \%$ & $35 \%$ & $2 \%$ \\
\hline \multirow{2}{*}{ B } & 1,727 & 762 & 458 & 407 & 100 \\
\cline { 2 - 6 } & $100 \%$ & $44 \%$ & $27 \%$ & $24 \%$ & $6 \%$ \\
\hline
\end{tabular}

A: Already formed in 2000. B: Did not exist in 2000; Newly formed between 2000 and 2014.

Source: Analysis by author.

of about $44 \%$ "Ger only". The Kha-shaas in Category B tended to form on slopes in the north.

Suburban area At Site 3, which took shape in suburban areas on the outskirts of the city, Kha-shaas had been relatively sparse in 2006, but by 2015, had formed across the entire area, with their numbers increasing by almost $250 \%$, from 1,969 to 5,193 (Figure 12, Table 7).

For 2015, Kha-shaas at each site were further divided into the following two categories: $(\mathrm{A})$ those that already existed in 2006; and (B) those that came into existence between 2006 and 2015 (Figure 13, Table 8). The Khashaas in Category A were located at sites with favorable conditions, such as along roads or on level ground,
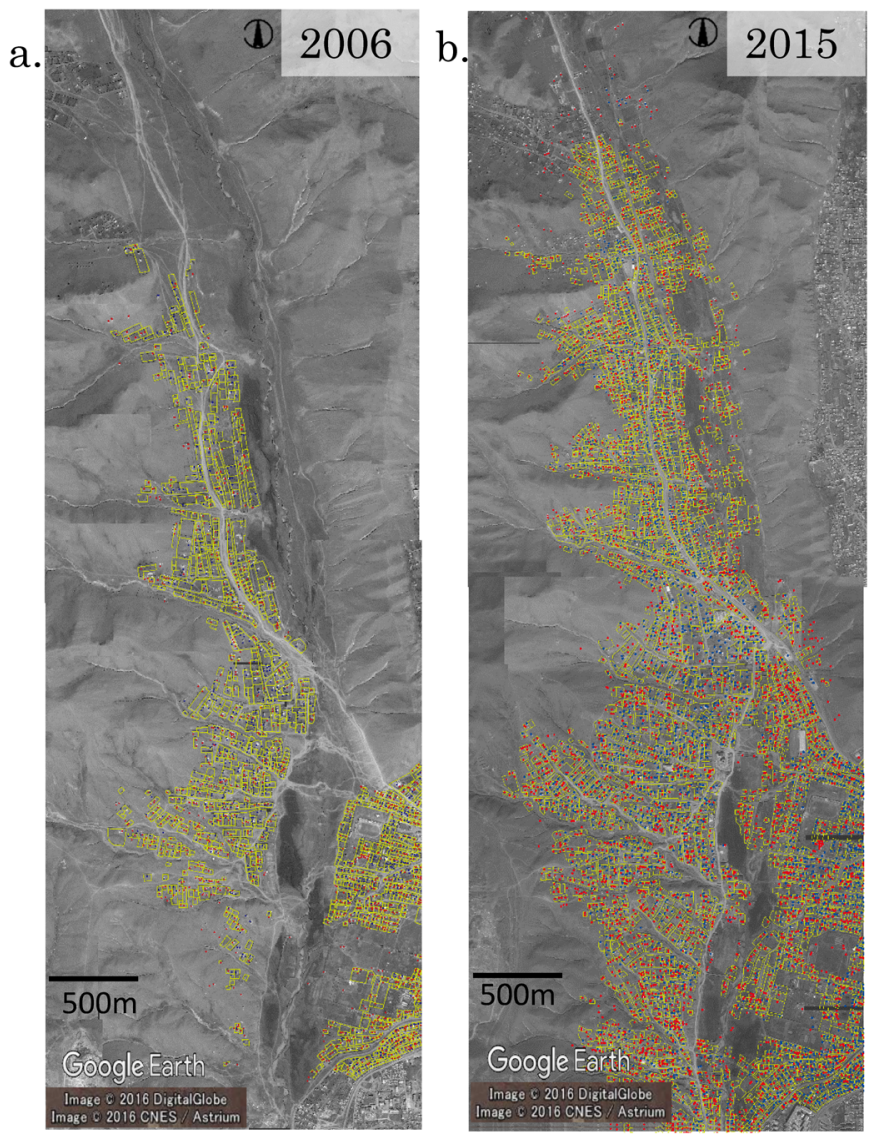

Kha-shaa

Ger

Bai-shin

Figure 12. Results of each identified Kha-shaa, Ger and Bai-shin at Site 3.

a. 2006 and b. 2015: Google Earth.

Table 7. Analysis of Internal changes in Kha-shaas of Site 3

\begin{tabular}{|c|c|c|c|c|c|}
\hline & $\begin{array}{c}\text { Total } \\
\text { Kha-shaa }\end{array}$ & $\begin{array}{c}\text { Ger } \\
\text { only }\end{array}$ & $\begin{array}{c}\text { Bai-shin } \\
\text { only }\end{array}$ & $\begin{array}{c}\text { Ger and } \\
\text { Bai-shin }\end{array}$ & Vacant \\
\hline \multirow{2}{*}{2006} & 1,969 & 779 & 498 & 331 & 361 \\
\cline { 2 - 6 } & $100 \%$ & $40 \%$ & $25 \%$ & $17 \%$ & $18 \%$ \\
\hline \multirow{2}{*}{2015} & 5,109 & 1,928 & 1,398 & 1,210 & 573 \\
\cline { 2 - 6 } & $100 \%$ & $38 \%$ & $27 \%$ & $24 \%$ & $11 \%$ \\
\hline
\end{tabular}

Source: Analysis by author.

whereas those in Category B were located at sites with less favorable conditions, such as on slopes outside the city. In addition, whereas $70 \%$ of the Kha-shaas in Category A were accompanied by Bai-shin, approximately half of those in Category B were "Ger only".

\section{Summary}

Through this analysis, Ger areas' expansion over time as a function of population growth has been shown. In recent years, having progressed from settling on land 
a.

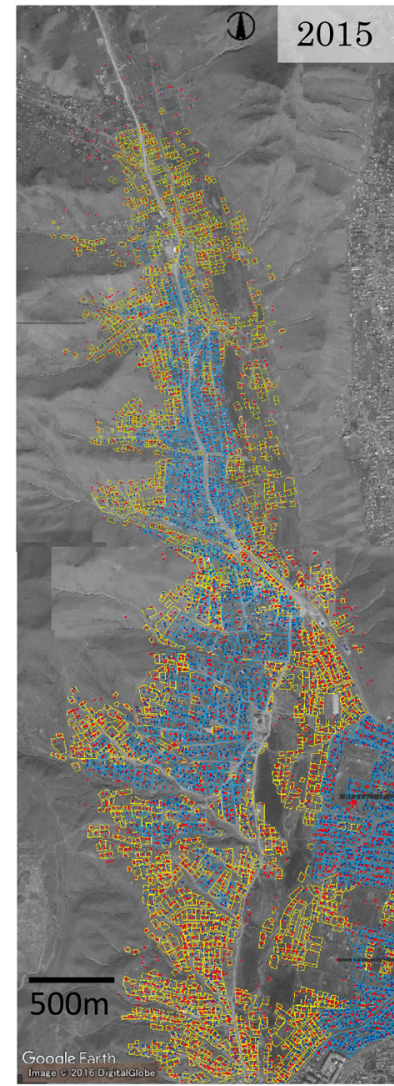

Already formed in 2006 (A)

Did not exist in 2006; newly formed between 2006 and 2015 (B)

Ger

Figure 13. Further divided Kha-shaas at Site 3.

a. 2015: Google Earth.

Table 8. Analysis divided into the following two categories of Site 3 in 2015

\begin{tabular}{|c|c|c|c|c|c|}
\hline & $\begin{array}{c}\text { Total } \\
\text { Kha-shaa }\end{array}$ & $\begin{array}{c}\text { Ger } \\
\text { only }\end{array}$ & $\begin{array}{c}\text { Bai-shin } \\
\text { only }\end{array}$ & $\begin{array}{c}\text { Ger and } \\
\text { Bai-shin }\end{array}$ & Vacant \\
\hline \multirow{2}{*}{ A } & 2,365 & 541 & 929 & 712 & 183 \\
\cline { 2 - 6 } & $100 \%$ & $23 \%$ & $39 \%$ & $30 \%$ & $8 \%$ \\
\hline \multirow{2}{*}{ B } & 2,744 & 1,387 & 469 & 498 & 390 \\
\cline { 2 - 6 } & $100 \%$ & $51 \%$ & $17 \%$ & $18 \%$ & $14 \%$ \\
\hline
\end{tabular}

A: Already formed in 2006. B: Did not exist in 2006; Newly formed between 2006 and 2015 .

Source: Analysis by author.

well suited to the formation of Kha-shaas, these enclosures have begun to take shape on less favorable plots of land characterized by harsher conditions. Furthermore, Ger areas can be classified into two groups; namely, sites remaining undeveloped since the socialist period, and sites that have formed since the transition to democracy. After the transition to democracy, no progress has been seen in the redevelopment of Ger areas to Apartment areas.
Although the expansion of Ger areas has been ongoing, a progressive housing shift from Gers to Bai-shin has been seen within individual Kha-shaas. In the study area, Site 1 is the oldest and closest to the city center, and Site 3 is the newest and farthest from the city center. Based on the results of analysis, Site 1 had the highest percentage of Bai-shin within its Kha-shaas. On the other hand, the proportion of Kha-shaas consisting of "Ger only" was the highest at Site 3. Especially at Site 3, in Category B, which represents new Ger areas, many Kha-shaa were categorized as "Ger only". Kha-shaas consisting of Bai-shin, such as Categories B and A at Sites 2 and 3, increased over time in chronological order of formation. Kha-shaas formed in 2000 at Site 2 (Category A) consisted of $80 \%$ Bai-shin by 2014, while those formed in 2006 at Site 3 (Category A) consisted of $70 \%$ Bai-shin by 2015. This finding suggests that Ger area residents initially settle in Gers for a period of about 10-15 years before building Bai-shin; this was particularly apparent at Site 3 in the suburbs. However, few significant changes were observed at sites that had already been established as Ger areas, such as Site 1 from 2003-2014. Although development has progressed from Gers to Bai-shin in newly formed Kha-shaas, a decrease has been seen in the actual number of Gers since sometime after the new formation of Kha-shaas.

\section{Consideration}

\section{Why have Gers not disappeared in Ger areas?}

The number of Kha-shaas consisting of "Ger only" has decreased over time, but the Gers in Ger areas have remained. Furthermore, the number of Kha-shaas consisting of Bai-shin has increased, but those consisting of Gers have remained. However, "Gers in Kha-shaas" may also not be used as residences.

According to interview surveys, residents who relocated to Ger areas built Bai-shin about 5-10 years later. Bai-shin have multiple rooms and are both safer and warmer than Gers. Therefore, Bai-shin are comfortable and convenient for urban living compared with Gers. Residents tend to build Bai-shin on their own when they have sufficient money and materials.

Therefore, there are two reasons that may explain why Gers have not disappeared. First, many people choose to dismantle their Ger after building a Bai-shin, while others choose to keep their Ger on their property to use as a relaxation space for talking and having tea time with family or friends, for providing a temporary place for visiting friends and acquaintances to stay, or even for such purposes as storage. Second, those who relocate from 
rural areas to Ulaanbaatar rely on family members and friends who live in Ger areas for temporary living quarters by Ger, or in other words, a temporary Ger residence ${ }^{5}$ (Matsumiya 2017).

\section{How Ger areas are formed?}

Through this analysis, the process characterizing the expansion of Ger areas seems to be as follows. First, newcomers find and move to vacant land where they construct Gers and take up residence. Next, they enclose their own land with a fence to form a Kha-shaa. A few years later, after they have established an adequate livelihood, they build Bai-shin, which are considered more suitable for urban settlement. After building their Bai-shin, the Ger is dismantled or used for different purposes, such as a relaxation space. After a few more years have passed, their friends and family members in rural areas relocate to the area bringing Ger and take up residence in the family's Kha-shaa. These people, once settled into a new life, find their own land, where they move with Ger. This process is then repeated, and current Ger areas were so constituted.

Accordingly, even though the presence of Gers diminishes over time after the establishment of a Kha-shaa, they do not disappear completely. Therefore, although the internal change is remarkable within new Kha-shaas in suburban areas, few significant changes have been observed at sites that had already been established as Ger areas in the previous decades.

\section{Closing remarks}

Ulaanbaatar has been regarded as "unique" based on the morphological uniqueness of Gers proliferated around the city. Living in Gers is meaningful in terms of the flexibility of an urban residence, and useful for residents who relocate from rural areas and require a temporary residence before acquiring their own land. Gers are therefore useful in a variety of situations. After building Bai-shin, Gers are typically used for relaxation spaces or other purposes, so living in a Ger is very rational in Ger areas.

In Ger areas, housing is upgraded from Gers to Baishin over time. Will Gers disappear in this area in the future? According to interview surveys, most Ger area residents would prefer to live in an apartment, which has better infrastructure and is much more comfortable. It is reasonable that living in an apartment would be considered more comfortable and convenient than living in a Ger because there is no longer the need to burn coal for heat or go to the water kiosk to buy water. However, due to a lack of financial resources among residents of
Ger areas owing to irregular employment, as well as an underdeveloped housing loan system, it is difficult for Ger area residents to move into an apartment by themselves. Therefore, Gers are not expected to disappear from Ulaanbaatar for at least the next 20-30 years.

Based on this analysis, the present status of Ger areas is characterized by a limited capacity of land and living environments accompanied by a lack of running water and sewage disposal. Kha-shaas have already been established on most of the land in favorable condition, so only the land in poor condition, such as slopes and areas far from the city center, remains. Therefore, the expansion of Ger areas is even more difficult than before and raises the question of how the next generation will live.

In future studies, it would be interesting to examine whether Gers will remain as the modernization of Ulaanbaatar continues to progress.

\section{Acknowledgements}

I am grateful to Prof. Enkhtaivan at the Institute of Geography and Geoecology, Mongolian Academy of Sciences, Prof. Suzuki and Dr. Ishii at Nagoya University for providing the extremely valuable aerial photographs used in this study. I am also grateful to Associate Prof. Narama and Mrs. Yamamoto at Niigata University for advice on using the aerial photographs for analysis, and to Prof. Kawaguchi and members of the Department of Geography at Meiji University for their advice. A summary of this paper was presented at the 11th Japan-Korea-China Joint Conference on Geography in September 2016 (Hotel New Otani Inn Sapporo).

\section{Notes}

1. The New Land Law states that the maximum surface area for land ownership is $700 \mathrm{~m}^{2}$ in the capital, $3,500 \mathrm{~m}^{2}$ in the permanent abode area (central area) of ai-mag, and $5,000 \mathrm{~m}^{2}$ in the permanent abode area of sum. According to this law, it is free for each person to register land, but only once, and land can be acquired by buying and selling.

2. Urban redevelopment in Ulaanbaatar has accelerated since 2012, when changes occurred in the housing administration. In this project, Ger areas were targeted for redevelopment to Apartment areas by the expropriation of land and adjustment of city lots in $\mathrm{Ger}$ areas. However, that project is not progressing according to plan because of problems in the legal system and a lack of financial resources. In addition, the project is likely to become even more complicated as another administration change occurred in 2016.

3. Dzud is cold season disaster due to dry, cold climate (Shinoda and Morinaga 2005). From 1998 to 2000, dzud occurred repeatedly, causing great damage to nomads, as many livestock, including sheep, died. Nomads who lost livestock, moved to Ulaanbaatar to 
seek jobs.

4. In Mongolia, 1990 is one of the most important year which transitioned to democracy. But no photo around 1990 which can analysis of accuracy same as another years. For example, the resolution of satellite data SPOT on 1999 is $10 \mathrm{~m}$.

5. Temporary Ger residence including children's household at marriage or independence but continue to live, until they find their own Kha-shaa, at parents' Kha-shaa in a Ger.

\section{References}

Amarsaikhan, D., Blotevogel, H. H., Ganzorig, M. and Moon, T. H. 2009. Applications of remote sensing and geographic information systems for urban land-cover change studies in Mongolia. Geocarto International 24: 257-271.

Amrjargal, N. 2012. The Study for Supporting Formulating Development Program in Ger Area, FINAL REPORT. JICA.

Batbold, B. and Majima, J. 1998. Housing policy and conditions in Mongolia. In Summaries of technical papers of annual meeting architectural institute of Japan. ed. Japan Society for Finishings Technology, 1083-1084. Tokyo: Japan Society for Finishings Technology. (J)

Chinbat, K. 2008. A study on the conflict between the traditional residence culture and housing policy: In the case of the Ger area in Ulaanbaatar, Mongolia. Urban Housing Sciences 63: 21-26. (J)

Chinbat, K. 2010. A comparative study on the residence awareness between the Ger area and an apartment complex in Ulaanbaatar: Consideration of the residence awareness and direction of the housing policy. Journal of Urban Sciences 3: 27-39. (J)

Fujimoto, Y. 2005. Mongoru-koku ni okeru shutoiju mondai: Moto yuubokumin ijuusha no korekara. Journal of Mongolian Studies 22: 46-62. (J)

Ishii, S. 2012a. Shakaishugi-go no Mongoru-Toshi no naka no yuuboku shakai-dai ni kai: Tochi-shiyuu to Gandan-ji Geruchiku no seikatsu (zenpen). Chiri 57(10): 24-36. (J)

Ishii, S. 2012b. Shakaishugi-go no Mongoru-Toshi no naka no yuuboku shakai-dai san kai: Tochi-shiyuu to Gandan-ji Geru-chiku no seikatsu (kouhen). Chiri 57(11): 64-72. (J)

Ishii, S. 2014a. Kyuusoku ni henbou suru Urambatoru: Tochi inhura no daikaizou. Chiri 59(7): 4-11. (J)

Ishii, S. 2014b. Urambatoru ni okeru Geru-chiku saikaihatsu- keikaku to juumin no hankyou. Chiri 59(8): 54-61. (J)

JICA. 2002. The Survey Report of the Living Environment of the Ger Area in Ulaanbaatar Mongolia: [Japanese edition] http:// open_jicareport.jica.go.jp/618/618/618_115_11836574.html (last accessed 13 December 2016)

Kamata, T., Reichert, J. A., Tsevegmid, T., Kim, Y. and Sedgewick, B. 2010. Enhancing Policies and Practices for Ger Area Development in Ulaanbaatar. http://siteresources.worldbank. org/INTMONGOLIA/Resources/Full_report_in_Eng.pdf World Bank (last accessed 13 December 2016)

Kushiya, K., Katou, Y., Kuroda, T., Kitamura, Y. and Ishizawa, S. 2007. Residents' intention and daily behavior in the Ger areas of Ulaanbaatar: Results of researches in 2005 \& 2006. The Japan-Sea Rim Studies Annual Report 14: 1-23. (J)

Matsumiya, Y. 2016. Everyday life of Ger areas in Ulaanbaatar. Studies in Arts and Letters-Meiji University Graduate School 45: 105-125. (J)

Matsumiya, Y. 2017. Residential career of Ger Areas' dwellers in Ulaanbaatar. Studies in Arts and Letters-Meiji University Graduate School 46: 147-168. (J)

Minato, K. 2002. Mongoru-koku tochi kanren houreishu. Jounal of Mongolian Studies 20: 101-137. (J)

Shinoda, M. and Morinaga, Y. 2005. Developing a combined drought-dzud early warning system in Mongolia. Geographical Review of Japan 78: 928-950. (JE)

Takiguchi, R. 2009. The instruction to become a "Landowner": Land privatization policies and the people in post-socialist Mongolia. Journal of the Center for Northern Humanities 2: 43-61. (JE)

Tsutsumida, N. 2013. "Tochi shiyuu-ka seisaku to shuto no supuroru genshou". In Mongoru sougenseitaikei nettowaku no houkai to saisei, ed. N. Fujita, S. Katou, E. Kusano and R. Sachida, 444-453. Kyoto: Kyoto Daigaku Gakujutsu Shuppankai. (J)

Tumenjargal, U. 2002. Study on change of the houses and land concept by democratization of the city of a socialist state. A master's thesis for graduate school of Osaka University. (J)

UN-Habitat 2010. Citywide Pro-Poor Ger Area Upgrading Strategy of Ulaanbaatar City. http://www.citiesalliance.org/ sites/citiesalliance.org/files/CAFiles/Projects/GUSIP_Output_ 1.6_-_Citywide_Pro-poor_Ger-area_Upgrading_Strategy_ December2010reduced.pdf (last accessed 13 December 2016)

(J) written in Japanese

(JE) written in Japanese with English abstract 